\title{
Ice thickness measurements and volume estimates for glaciers in Norway
}

\author{
L.M. ANDREASSEN, ${ }^{1}$ M. HUSS, ${ }^{2,3}$ K. MELVOLD,${ }^{1}{ }^{H}$ H. ELVEH $\varnothing Y,{ }^{1}$ S.H. WINSVOLD ${ }^{1,4}$ \\ ${ }^{1}$ Norwegian Water Resources and Energy Directorate (NVE), Oslo, Norway \\ ${ }^{2}$ Department of Geosciences, University of Fribourg, Fribourg, Switzerland \\ ${ }^{3}$ Laboratory of Hydraulics, Hydrology and Glaciology (VAW), ETH Zürich, Zürich, Switzerland \\ ${ }^{4}$ Department of Geosciences, University of Oslo, Oslo, Norway \\ Correspondence: L.M. Andreassen<lma@nve.no>
}

\begin{abstract}
Glacier volume and ice thickness distribution are important variables for water resource management in Norway and the assessment of future glacier changes. We present a detailed assessment of thickness distribution and total glacier volume for mainland Norway based on data and modelling. Glacier outlines from a Landsat-derived inventory from 1999 to 2006 covering an area of $2692 \pm 81 \mathrm{~km}^{2}$ were used as input. We compiled a rich set of ice thickness observations collected over the past 30 years. Altogether, interpolated ice thickness measurements were available for $870 \mathrm{~km}^{2}(32 \%)$ of the current glacier area of Norway, with a total ice volume of $134 \pm 23 \mathrm{~km}^{3}$. Results indicate that mean ice thickness is similar for all larger ice caps, and weakly correlates with their total area. Ice thickness data were used to calibrate a physically based distributed model for estimating the ice thickness of unmeasured glaciers. The results were also used to calibrate volume-area scaling relations. The calibrated total volume estimates for all Norwegian glaciers ranged from 257 to $300 \mathrm{~km}^{3}$.
\end{abstract}

KEYWORDS: glacier mapping, glacier modelling, ground-penetrating radar, ice cap, mountain glaciers

\section{INTRODUCTION}

Knowledge of glacier volume is important for assessing the cryospheric contribution to sea-level rise, glacier response to climate change (Vaughan and others, 2013), and water resource management at the local to regional scale (Jones, 1999; Hock and others, 2006). An estimate of ice volume and its spatial distribution is a prerequisite for glacier runoff projections. Whereas glacier areas in many mountain regions around the globe are well surveyed using optical satellite sensors, and data on glacier area are available in digital inventories (e.g. Kargel and others, 2014; Pfeffer and others, 2014), measurements of ice thickness are sparse by comparison, and a global dataset does not exist. Due to lack of information on ice thickness, ice volume is often estimated using empirical or physical scaling relationships (e.g. Van de Wal and Wild, 2001; Radić and Hock, 2010). Volume-area $(V-A)$ scaling is a commonly used method as it requires only glacier area as input (Chen and Ohmura, 1990), with just two adjustable parameters determined empirically from regression of glacier data (e.g. Chen and Ohmura, 1990) or from theoretical analyses (Bahr, 1997; Bahr and others, 1997). Several scaling relationships are proposed; some are regional and some are used globally (Grinsted, 2013). Estimations may have gross errors for individual glaciers, but the uncertainty is reduced for larger glacier samples (Meier and others, 2007). A minimum sample size of $\sim 100$ glaciers is recommended (Bahr, 2012; Farinotti and Huss, 2013). Although more accurate scaling relations can be obtained through characterization of individual glacier shape, slope and size (Adhikari and Marshall, 2012; Grinsted, 2013) and by local calibration, scaling approaches still have large uncertainties (Haeberli and Hoelzle, 1995; Cogley, 2012; Farinotti and Huss, 2013). Scaling does not, for instance, account for individual glacier characteristics such as surface geometry or local climate, and does not provide information on the spatial distribution of ice thickness. Thus, alternative methods are needed to obtain glacier-specific ice volume and distributed ice thickness.

Recent studies have demonstrated that glacier ice thickness distribution can be estimated using physically based approaches based on a digital terrain model (DTM) and glacier outlines (e.g. Clarke and others, 2009, 2013; Farinotti and others, 2009) or by using a DTM, glacier outlines and flowlines (Paul and Linsbauer, 2012). Application of such approaches is possible at the global scale (Huss and Farinotti, 2012) but can also be calibrated for regional studies (Linsbauer and others, 2012).

In a previous inventory of glaciers in northern Scandinavia, ice volume was estimated by simply assuming mean thickness per size class (Østrem and others, 1973). In the inventory of South Norway, measurements of Swedish valley glaciers were used to assess the relation between glacier area and volume and to calculate ice volume within river basins (Østrem and others, 1988). Since the 1980s, ice thickness measurements have been carried out by radioecho sounding (RES) on many glaciers in Norway. Measurements were conducted on smaller mountain glaciers as well as on the largest ice caps. So far, however, a total ice volume estimate for Norway has not been derived from these data. Here we provide an overview of ice thickness measurements available for mainland Norway, use a distributed model (Huss and Farinotti, 2012) to interpolate data and to derive an ice volume estimate for all individual Norwegian glaciers, and compare measured ice volume with results from various $V-A$ scaling relations.

\section{DATA}

\subsection{Ice thickness data}

We used all ice thickness data that were available in digital format (Table 1; Fig. 1). The source of the data is the 


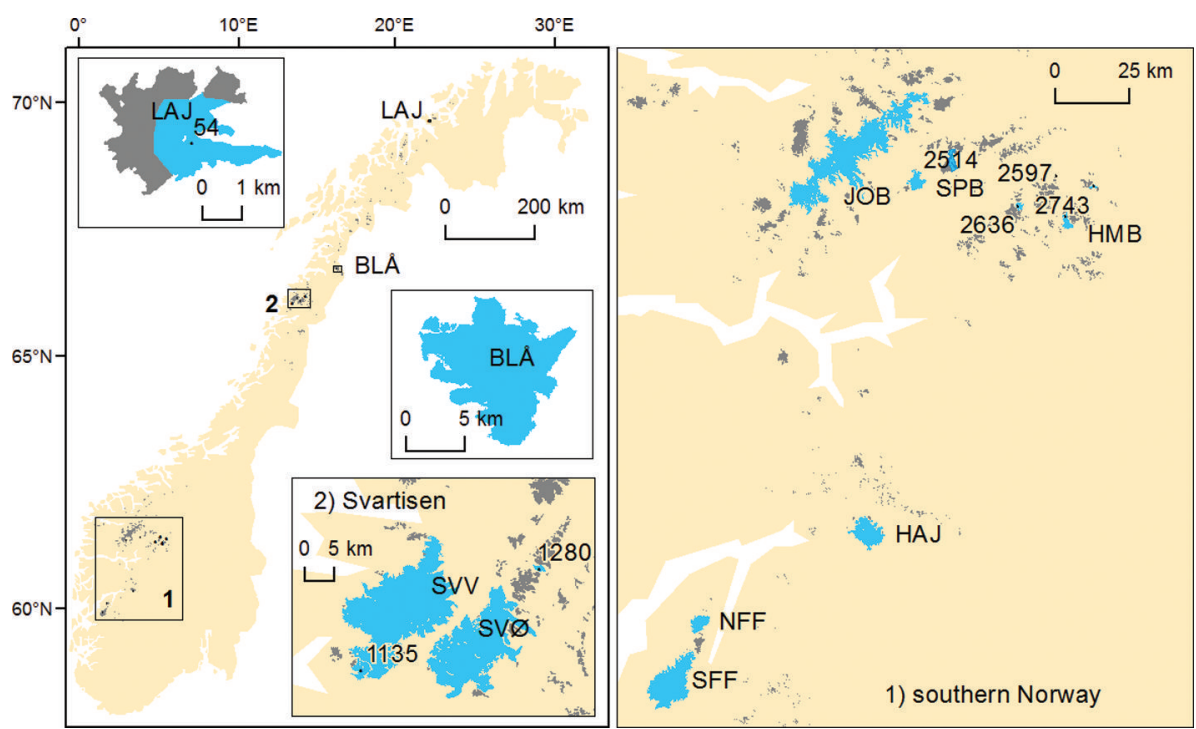

Fig. 1. Location map of glaciers with ice thickness measurements in Norway used in this study. Insets show southern Norway (1), Svartisen (2), Blåmannsisen (BLÅ) and Langfjordjøkelen (LAJ). Glaciers with ice thickness measurements are in blue, others in grey. Numbers refer to glacier ID and letters to glacier complex code (Table 1).

database of the Norwegian Water Resources and Energy Directorate (NVE), with a few additions from collaborators. Information on the data collection and processing is documented in individual reports and papers, where available (Table 1). Although there might be other thickness measurements in Norway of which we are not aware, or to which we do not have data access, we are confident that our thickness data compilation includes most measurements.

The first measurements of glacier thickness were carried out on Austerdalsbreen in the 1950s, using gravity measurements and hot-water drilling (Bull and Hardy, 1957; Ward, 1961). Other investigations in the 1960s and 1970s used seismic soundings at Folgefonna and Hardangerjøkulen (NGU, 1964; Sellevold and Kloster, 1964) and hot-water drilling at Nigardsbreen (Østrem and others, 1976), but measurements were sparse and only covered minor parts of the glaciers. In 1981, the Glacier Office at NVE (now Section for Glaciers, Ice and Snow) purchased a noncommercial RES instrument for ice thickness measurements (Sverrisson and others, 1980). Measurements were conducted using this ground-based RES system on many glaciers including the largest ice caps, Jostedalsbreen, Svartisen, Folgefonna, Blåmannsisen and Hardangerjøkulen, from the early 1980 s onwards. As it is difficult to access heavily crevassed outlets, helicopter-borne RES measurements have also been conducted (Kennett and others, 1993). Data were typically published in contract reports by NVE, and a few in peer-reviewed publications, while some investigations remained unpublished (e.g. investigations at Trollbergdalsbreen and Svartisen-Østisen; Table 1). Data reporting varies: some reports contain ice thickness maps and give the maximum thicknesses; others contain only surface and bedrock topography maps, since deriving the hydrological drainage divides was often the main purpose of the investigations. In recent years, new studies have been conducted, both in order to extend measurements on already surveyed glaciers (Melvold and others, 2011) and to obtain data for unmeasured glaciers (Andreassen and others, 2012a). The RES equipment, an impulse radar with antennas whose centre frequency is typically $10 \mathrm{MHz}$, has changed little since its introduction (Sverrisson and others,
1980). Currently the receiver comprises a 12-bit analogue/ digital (A/D) converter at 100 Msamples s $^{-1}$ with each stored trace stacked 8-16-fold (e.g. Pettersson and others, 2011). Navigation has been improved using global navigation satellite systems (GNSS). In the first years of recording, postprocessing was done manually. Gradually, digital procedures were introduced, and today all data processing is performed digitally. Some of the older data are therefore not available in digital format but as analogue maps. Data have also been collected by other parties (e.g. Ødegård and others, 2011; Førre, 2012).

The measured glaciers include the largest ice caps, with numerous outlets, such as Jostedalsbreen $\left(474 \mathrm{~km}^{2}\right)$ and Svartisen-Vestisen; smaller ice caps such as Langfjordjøkelen; valley and cirque glaciers such as Trollbergdalsbreen, Storbreen and Hellstugubreen; and the small ice patch Juvfonne $\left(0.15 \mathrm{~km}^{2}\right)$. On some glaciers, only a few measurements are available, while on others the dataset is dense and provides good spatial coverage (e.g. Fig. 2). Almost all RES measurements were carried out in spring (March-May) when the ice surface is covered by winter snow and a snowmobile is used to carry the equipment. A few RES measurements are also carried out in summer/early fall (e.g. Hallaråker and Lohne, 2013; Sørdal, 2013). Uncertainties in the measured and interpolated ice thickness data are discussed in Section 3.1.1.

\subsection{Glacier inventory data}

Glacier outlines, area and other inventory parameters are sourced from the newest glacier inventory of Norway published by NVE in 2012 (Andreassen and others, 2012b; available at www.nve.no/glacier). The inventory was derived from Landsat imagery acquired during 1999-2006. Glacier outlines were mapped using the established bandratio method following recent guidelines and recommendations (Paul and others, 2009; Racoviteanu and others, 2009), and are available online from the Global Land Ice Measurements from Space (GLIMS) database (www.glims.org).

All automatically mapped snow and ice polygons from the band-ratio method (using bands red/SWIR (shortwave infrared)) were visually inspected using composites of 
Table 1. Ice thickness measurements in Norway used in this study (see Fig. 1 for locations). Glaciers are sorted with the largest complexes first (NO 1-26), then measurements for other glaciers (ID 54-2743) arranged by size. Glacier complex codes, glacier IDs and area ( $A_{\text {tot }}$ ) are from the recent glacier inventory of Norway (Andreassen and others, 2012b). Max is measured maximum ice thickness. $V_{\text {calc }}$ is calculated glacier volume from the measurements. $\sigma$ is uncertainty in interpolated volume (15-20\%). $A_{\text {int }}$ is area of interpolation; in cases where $A_{\text {int }}<A_{\text {tot }}$ mean thickness, $T$, is calculated for $A_{\text {int. }}$ Type is data source (c: digitized bed contours; p: measured point data). Uncertainty refers to the point measurements. Units are number of units from the complex used for calibration of the distributed model and $V$ - $A$ coefficients

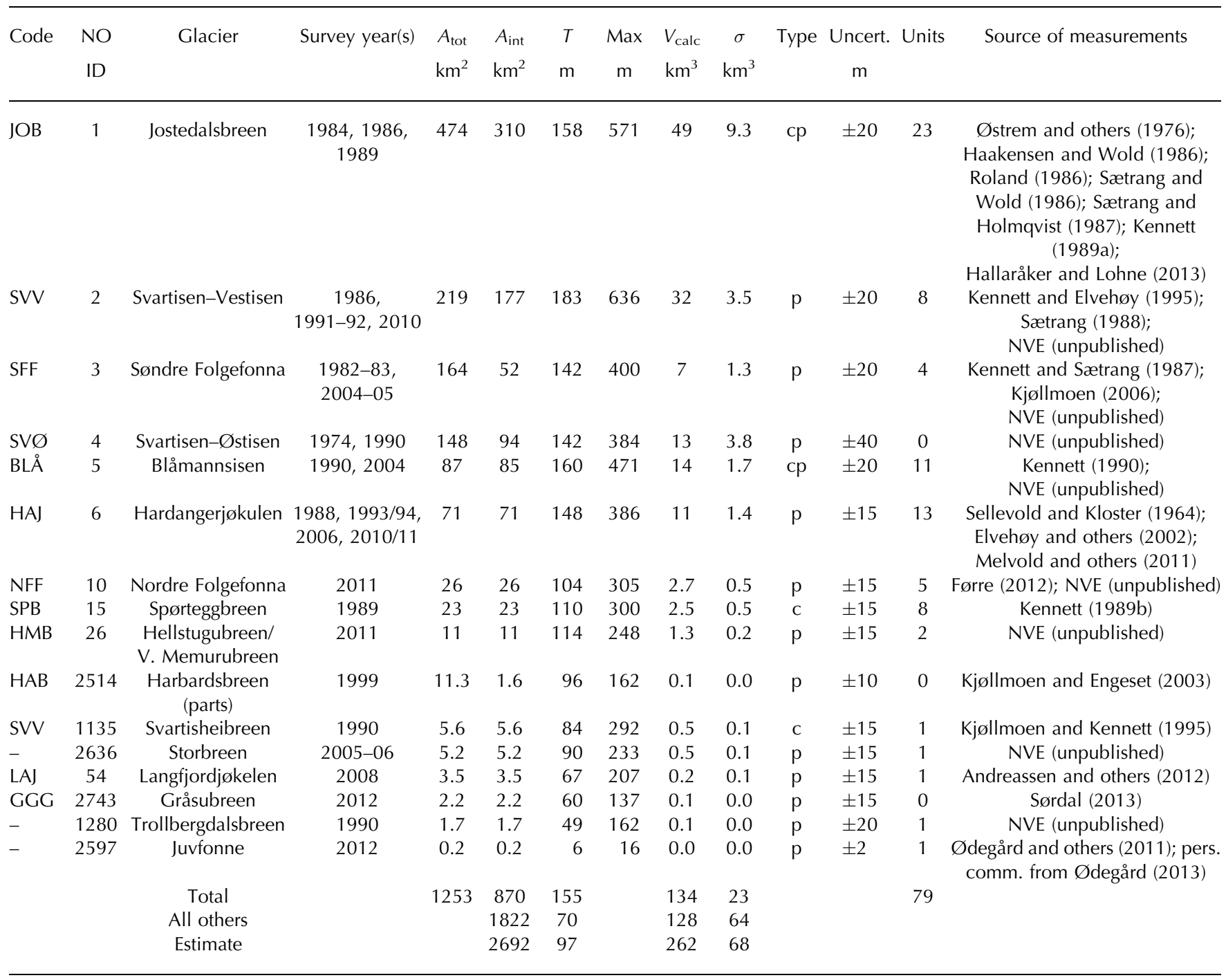

satellite image bands, digital topographic maps and orthophotos where available. All polygons to be included in the inventory were assigned a unique ID. Glacier complexes were divided into glacier flow units using drainage divides defined by glacier surface topography (Fig. 3). Glacier complexes were assigned a glacier complex code to be able to differentiate between glacier complexes and single glaciers (Fig. 3).

In total, 3143 glacier units were included in the new inventory. They are hereafter referred to as glaciers. The total glacier area is $2692 \pm 81 \mathrm{~km}^{2} ; 1523 \mathrm{~km}^{2}(57 \%)$ is located in southern Norway, and $1169 \mathrm{~km}^{2}(43 \%)$ in northern Norway.

\subsection{Digital terrain model}

Topographic parameters for the ice thickness calculations were derived from the national DTM with $20 \mathrm{~m}$ resolution (DTM20), which covers all of Norway, provided by the Norwegian mapping authorities (Statens kartverk). The DTM was put together from contours and elevation points from the main map series of Norway 1:50000 and is the same as used for the glacier inventory, with some updates. The reported vertical root-mean-square error (RMSE) of the DTM20 is $2-6 \mathrm{~m}$, but the accuracy and the mapping data vary from region to region. Over recent years the maps providing the base of the DTM have gradually been updated with data from new aerial photos from the 2000s, but not all regions are yet updated. The DTM20 is thus based on glacier extent and surface topography from different years, and not necessarily close in time to the Landsat imagery used for compilation of the glacier inventory.

\section{METHODS}

\subsection{Interpolating ice thickness measurements}

The ice thickness data were used to interpolate thickness maps for estimating total glacier volume and calibrating the distributed model. Data collected prior to 1989 were often available only as hand-drawn bed contour maps (e.g. for Svartisheibreen and Blåmannisen (Fig. 2), Spørteggbreen and Jostedalsbreen). For some of these glaciers newer point 

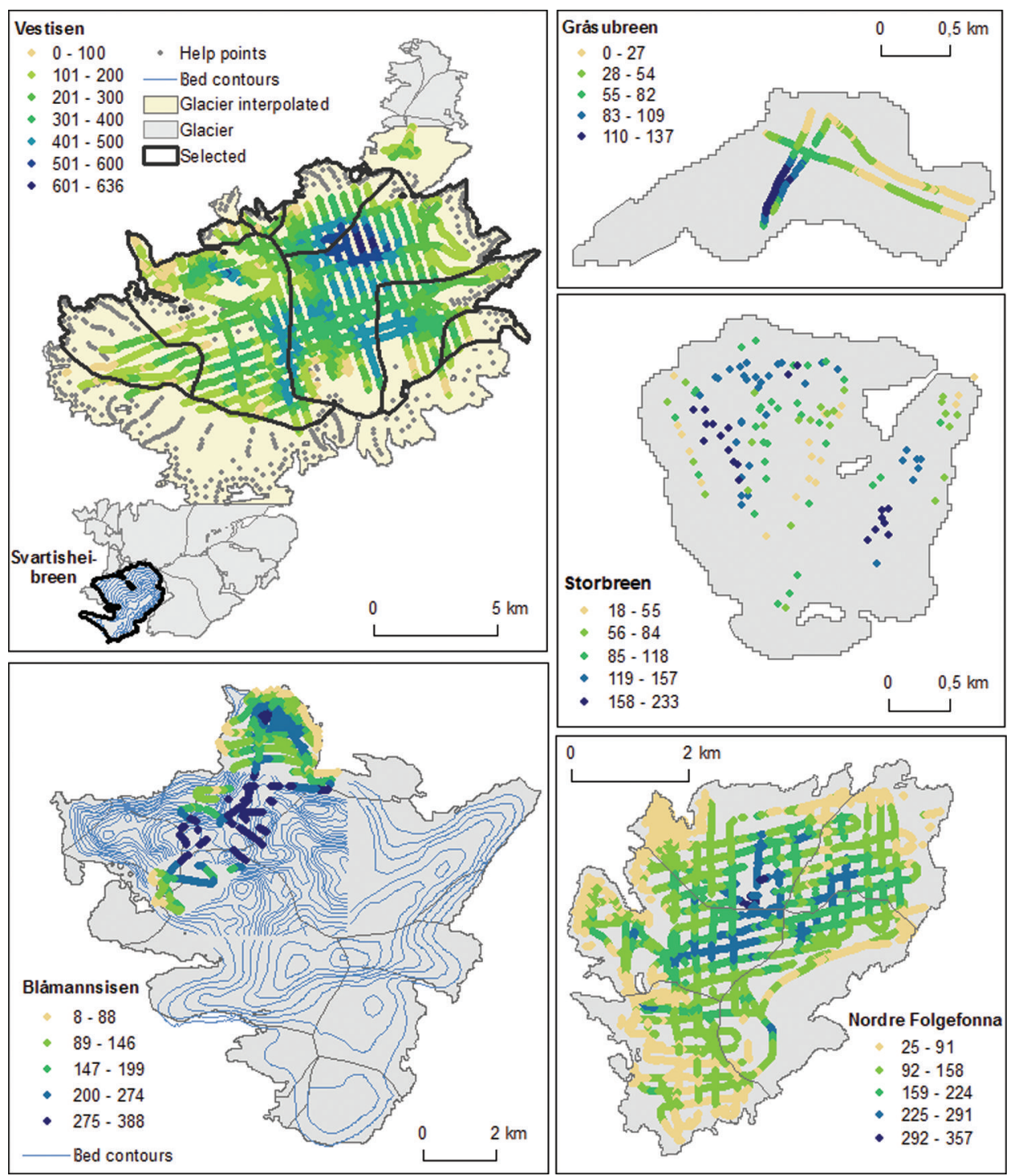

Fig. 2. Examples of various ice thickness data: Vestisen (SVV), Blåmannsisen (BLÅ), Gråsubreen (2743), Storbreen (2636) and Nordre Folgefonna (NFF). See Figure 1 for locations. Vestisen has been measured in several campaigns, and bed contours are available for Svartisheibreen. Ice thickness of Blåmannsisen was derived from interpolated bed contours made from campaigns in 1989 covering large parts of the glacier and additional measurements of Rundvassbreen in 2004. At Gråsubreen, three profiles were collected in fall 2012. At Storbreen, point measurements were collected in 2005 and 2006. At Nordre Folgefonna, dense measurements were performed in 2012.
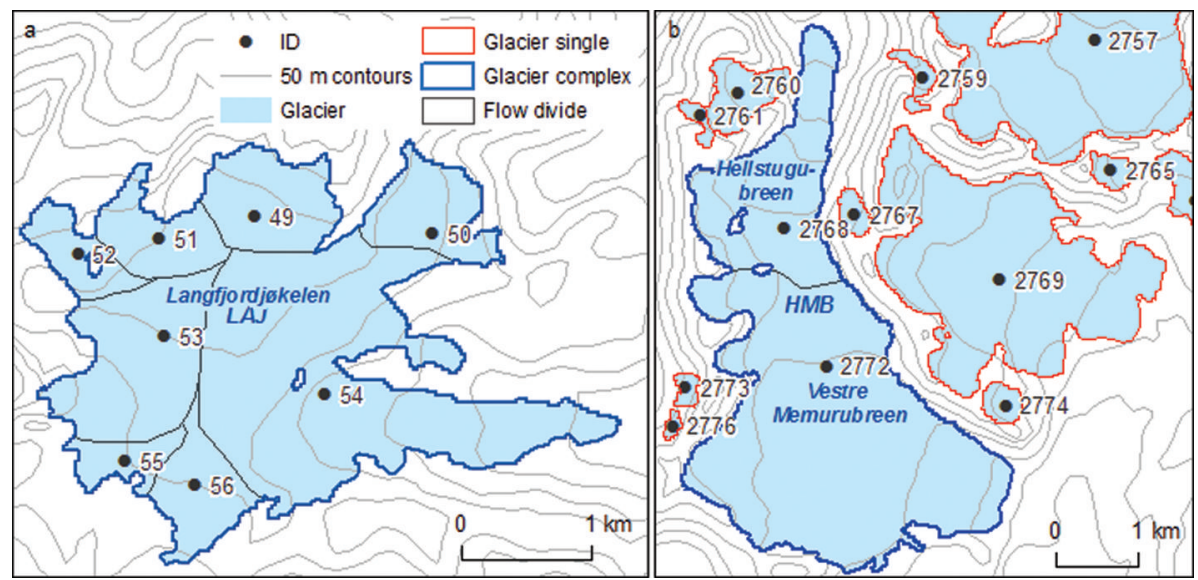

Fig. 3. Illustration of glacier flow units and glacier complexes for (a) Langfjordjøkelen, northern Norway, and (b) a section in Jotunheimen, southern Norway. To create an inventory of individual glaciers the glacier complexes are divided into glacier units using flow divides. Langfjordjøkelen (LAJ) is a complex divided by flow divides into eight units with individual IDs 49-56, and the Hellstugubreen/Vestre Memurubreen (HMB) complex consists of two units (IDs 2768 and 2772) and is surrounded by many single glaciers that are not part of complexes. 
data were also available (Table 1). Whereas these bed contour maps are generally based on interpolation of measurements with good spatial coverage, the Jostedalsbreen bed contour map was hand-drawn for visual purposes and lacks measurements in many parts. Where no measurements were available, the bed map was drawn from best guess using surface topography and slope. Although we excluded glaciers from the ice cap that were lacking ice thickness measurements, the volume estimate is more uncertain when the original data are not available digitally.

For glaciers with bedrock maps, contours were digitized and point datasets of ice thickness were extracted using current surface topography, either from detailed DTMs based on laser scanning, where available, or from the DTM20. Newer data collected since 1990 were available in digital format as point datasets and used directly. Point datasets were then interpolated to ice thickness grids using the function 'Topo to raster' in ArcGIS, based on the ANUDEM program (e.g. Hutchinson, 1989), with glacier outlines used as boundary condition where ice thickness is zero. The 'Topo to raster' function was preferred as it works well with contour inputs and can combine both contour and point data (Fischer and Kuhn, 2013).

Glaciers with available data used for interpolation and/or validation are summarized in Table 1. Our dataset includes nine glacier complexes with numerous outlet glaciers, four glaciers that are part of glacier complexes and three single glaciers (Storbreen, Trollbergdalsbreen and Juvfonne). The total area of all glaciers with ice thickness measurements is $1227 \mathrm{~km}^{2}$. However, as measurements were sparse for some parts of the glaciers and data coverage was not sufficient for interpolation, non-measured areas were masked out from the interpolated ice thickness maps. Hence, ice thickness was interpolated for $870 \mathrm{~km}^{2}$, accounting for $32 \%$ of Norway's total glacier area (Table 1). From the dataset we selected 79 glaciers considered to have sufficient coverage for calculating mean thickness. The 79 units range in size from $0.15 \mathrm{~km}^{2}$ (Juvfonne) to $47.6 \mathrm{~km}^{2}$ (Tunsbergdalsbreen, JOB). The total area of these glaciers is $628 \mathrm{~km}^{2}, 24 \%$ of Norway's glacier area.

\subsubsection{Uncertainties}

Common uncertainties for all ice thickness measurements arise from the propagation velocity of electromagnetic waves in snow, firn and ice, inaccuracies when picking reflectors, and the resolution of the radar system. Only data collected in recent years have been analysed with two-dimensional migration methods to improve ice thickness and bedrock determination in steep terrain. The effect of not carrying out migration could significantly increase the error in estimated ice thickness on steep slopes (Moran and others, 2000). However, as most of the older RES has been collected in easily accessible terrain (without steep slopes and crevasses) this effect is assumed to be small. Uncertainty in determining bedrock elevation is also affected by inaccurate positioning of radar traces, and uncertain surface elevations. Although methods have been basically the same for almost all RES data used in this study, the older data have more uncertainties in positioning and surface topography. The effect of each uncertainty component on the total error will vary depending on local conditions, reference data, position precision, etc. To assess the accuracy of the measurements, it is standard procedure to compare ice thickness at profile intersections where crossover points are available (e.g. Kennett and others, 1993; Petterson and others, 2011; Andreassen and others, 2012a). The overall error in ice thickness points is typically estimated to be $\pm 15 \mathrm{~m}$ when measured with $10 \mathrm{MHz}$ RES (Sætrang and Wold, 1986; Kennett, 1990). Table 1 provides error estimates in the point measurements for each of the glaciers in our dataset.

For the interpolation from point measurements to mean thickness of glaciers or glacier complexes, the representativeness of the measured points is important (e.g. Fischer, 2009; Navarro and Eisen, 2010). For practical reasons, ice thickness measurements are typically acquired along profiles not equally distributed over the glacier. Thus, the accuracy of the ice thickness data points is not necessarily consistent with the accuracy of mean thickness (e.g. Fischer, 2009). The uncertainty in interpolated ice thicknesses depends on distance to the nearest data point and local terrain. Measurements are biased towards more gently sloping parts of the glacier, whereas measurements in steeper regions are scarce. The effect of using the 'Topo to raster' interpolation compared to other automatic interpolation algorithms (e.g. kriging, inverse distance weighting or spline) was tested on Hardangerjøkulen, and the effect on mean ice thickness was small $( \pm 2 \mathrm{~m})$. The representativeness of the point data is more important for the interpolated ice thickness than the interpolation method used. The ice thickness dataset also spans several decades, and the surface topography and inventory data refer to different years. We have eliminated some of the uncertainty by referring the ice thickness or bed topography data to 'current' topography to obtain 'current' ice thicknesses, wherever possible. Data are meant to be representative for the period 1999-2011. We estimated the error in mean interpolated ice thickness at 15$20 \%$. The best relative accuracy (15\%) was expected for glaciers with dense spatial coverage and new digital data such as Hardangerjøkulen, Nordre Folgefonna and Hellstugubreen/Vestre Memurubreen.

\subsection{Distributed ice thickness}

\subsubsection{Model description}

To calculate the ice thickness distribution of glaciers in Norway we use the approach by Huss and Farinotti (2012) that has been applied to a global dataset and represents a further development of the model described by Farinotti and others (2009). The model estimates the surface massbalance distribution, calculates the volumetric balance flux and converts it into thickness using the flow law for ice (Glen, 1955) with a digital glacier mask and a DTM as input. Mean ice thickness is calculated in elevation bins along a longitudinal profile, and the ice thickness is finally extrapolated by inverse-distance weighting, resulting in an ice thickness estimate for every gridcell of the glacier. Below we briefly describe the principles and discuss the adaptation and calibration of the model to Norwegian glaciers.

First, the DTM was intersected with the glacier outlines, providing area $S_{i}$ and mean slope $\alpha_{i}$ for all glacier surface elevation bands $i$. We chose a vertical spacing of elevation bands $\mathrm{dz}=10 \mathrm{~m}$. Width $w_{i}$ of each elevation band is obtained with $w_{i}=S_{i} / l_{i}=S_{i} \tan \left(\alpha_{i}\right) / \mathrm{d} z$, where $l_{i}$ is the horizontally projected length of the elevation band. The threedimensional geometry is thus reduced to a simplified twodimensional (2-D) shape of the glacier.

To conserve mass, surface mass balance $b$ must be balanced by ice flux divergence and the surface elevation change $\partial h / \partial t$. Following Farinotti and others (2009), $b$ and 
$\partial h / \partial t$ are lumped into a new variable, the 'apparent mass balance', $\widetilde{b}$, defined as

$$
\widetilde{b}=b-\rho \frac{\partial h}{\partial t}
$$

where $\rho$ is the ice density. This allows direct calculation of the balancing ice volume flux, including for glaciers that do not have steady-state geometry. The apparent mass-balance distribution is calculated using a reference altitudinal gradient $\mathrm{d} \widetilde{b} / \mathrm{d} z_{0}$. As demonstrated by Rasmussen and Andreassen (2005), mass-balance gradients are remarkably linear in Norway and vary little from year to year. We therefore used a linear gradient and did not introduce a smaller gradient in the accumulation area, as did Huss and Farinotti (2012). For glaciers smaller than a critical area $S_{\text {crit, }}$ $\mathrm{d} \widetilde{b} / \mathrm{d} z_{0}$ is reduced linearly with glacier area. This reduction is carried out since flow dynamics are less important for a change in $\mathrm{d} h / \mathrm{d} t$ on small glaciers (Huss and Farinotti, 2012). Gradients of annual balance in Norway are greatest (6.4$8.7 \mathrm{mw}$.e. $\mathrm{km}^{-1}$ ) at maritime glaciers, and lower (5.7$6.1 \mathrm{mw}$ w.e. $\mathrm{km}^{-1}$ ) for more continental glaciers (Rasmussen and Andreassen, 2005). We used a continentality index $C$ to adjust the reference apparent surface mass-balance gradient $\mathrm{d} \widetilde{b} / \mathrm{d} z_{0}$ to local conditions. Values of $C$ were calculated from the equilibrium-line altitude (ELA) of each glacier, derived from its median elevation, and a latitude-dependent reference ELA as described in Huss and Farinotti (2012), with a continentality index as a constant parameter $f_{\text {cont }}=$ $2400 \mathrm{~m}$. $C$ is used to adapt the reference apparent surface mass-balance gradient $\mathrm{d} b / \mathrm{d} z_{0}$ to local conditions.

$$
\frac{\mathrm{d} \widetilde{b}}{\mathrm{~d} z}=\frac{\mathrm{d} \widetilde{b}}{\mathrm{~d} z_{0}} C
$$

For each glacier, the apparent mass-balance distribution is computed using the gradient $\mathrm{d} \widetilde{b}$ with the ELA that yields a balanced mass budget. Then the volumetric balance flux $q$ for each elevation band $i$ of the glacier is calculated by integration of $b$ along the glacier.

To obtain ice thickness using Glen's (1955) flow law, we need to account for the fraction of flux attributed to sliding at the glacier base. Volumetric flux is therefore multiplied by $\left(1-f_{\mathrm{sl}}\right)$, a factor assumed to be constant along the glacier. $f_{\mathrm{sl}}$ varies between 0 and 0.55 and is calculated from the area and continentality $C$ for each glacier (see Huss and Farinotti, 2012, for details and parameters).

The ice thickness $h_{i}$ for every elevation band $i$ is then computed as

$$
h_{i}=\sqrt[n+2]{\frac{\left(1-f_{\mathrm{sl}}\right) q_{i}}{2 A_{\mathrm{f}}} \frac{n+2}{\left(F_{\mathrm{s}, \mathrm{i}} \rho g \sin \bar{\alpha}_{i}\right)^{n}}}
$$

with $q_{i}$ the ice flux normalized by glacier width, $f_{\mathrm{sl}}$ the factor accounting for basal sliding, $n=3$ the exponent of the flow law, $\rho$ the ice density, $g$ the acceleration due to gravity, and $F_{\mathrm{s}, \mathrm{i}}=w_{i} /\left(2 h_{i}+w_{i}\right)$ a valley shape factor (Nye, 1965). The rate factor of the flow law, $A_{\mathrm{f}}$, is assumed to be $0.075 \mathrm{bar}^{-3} \mathrm{a}^{-1}$ for temperate glaciers (see, e.g., Gudmundsson, 1999). Glaciers in Norway are temperate with a few exceptions (Andreassen and others, 2012b). Hence, considering temperature effects on $A_{\mathrm{f}}$ is not necessary (see also Clarke and others, 2013).

Finally, the mean elevation band thickness $h_{i}$ is extrapolated from the simplified 2-D shape of the glacier to a regular grid by weighting the distance to the closest glacier boundary point and prescribing a weight proportional to $(\sin \alpha)^{n /(n+2)}$ based on Eqn (3) (see also Farinotti and others, 2009). The assumption that local thickness at the glacier boundary is zero is not applied at ice divides, where we directly assign the mean thickness of the respective elevation band. This extrapolation scheme conserves elevation band ice volume, and results in an estimate of ice thickness for each gridcell of every glacier (see Fig. 4).

\subsubsection{Calibration, validation and uncertainty}

To calibrate and test the performance of the model, calculated ice thicknesses were compared with point datasets of ice thickness and with average interpolated ice thicknesses for individual glaciers. Ice thickness point measurements of 32 glaciers in Norway were used in a first phase. The modelled ice thickness $h_{\text {mod }}$ was compared with measured ice thickness $h_{\text {meas }}$ on a point-by-point basis. All available point thickness observations and corresponding calculated thicknesses for the same locations were then arithmetically averaged, providing one mean value per glacier. The apparent mass-balance gradient $\mathrm{d} \widetilde{b} / \mathrm{d} z_{0}$ and $S_{\text {crit }}$ were varied among physically reasonable bounds to test the sensitivity of the results on the chosen parameters and to study model performance relative to measured point data. We also varied other model parameters to assess their impact on the results, but chose to keep the reference values used by Huss and Farinotti (2012). In a second phase, interpolated mean ice thickness from glaciers was compared with mean thickness calculated by the distributed model for the same glaciers. The model was calibrated by adjusting $\mathrm{d} \widetilde{b} / \mathrm{d} z_{0}$ and $S_{\text {crit }}$ to minimize the error in mean thickness of all glaciers and to fit the modelled volume of all 79 glaciers so it agreed with the volume interpolated from measurements.

For $\mathrm{d} \widetilde{b} / \mathrm{d} z_{0}=0.007 \mathrm{~m}$ w.e. $\mathrm{m}^{-1}$ and $S_{\text {crit }}=10 \mathrm{~km}^{2}$ the difference between the average of modelled and observed ice thickness $\left(h_{\Delta}=h_{\text {mod }}-h_{\text {meas }}\right.$ ) was $0 \mathrm{~m}$ for mean thickness, and $-10 \mathrm{~m}$ for the mean of point data of the 32 glaciers. Results further revealed a RMSE of $28 \mathrm{~m}$ (Fig. 5) of $h_{\Delta}$ for the interpolated mean ice thickness from the 79 glaciers. Although relatively large $h_{\Delta}$ were found for some glaciers, 52\% (70\%) of the units were in agreement within \pm 20 (30) $\mathrm{m}$. This is within the uncertainty of the interpolated measurements.

To evaluate the model results, the thickness maps were also visually compared with interpolated maps. Modelled thickness distributions for the glacier complex Hellstugubreen/Vestre Memurubreen, which is densely covered by RES measurements, show a good qualitative agreement (Fig. 3). $h_{\Delta}$ was -1 and $13 \mathrm{~m}$, respectively. The modelled and interpolated volume based on measurements for the glacier complex are 1.19 and $1.27 \mathrm{~km}^{3}$, respectively. The model captures the general pattern of ice thickness distribution but disagrees with the observations for some regions of the glacier. This can be attributed to simplifications in the methodology, which does not use additional linear information such as manually assigned flowlines. Results from Hardangerjøkulen (Fig. 6) showed that, although $h_{\Delta}$ varies among the glaciers from $-26 \mathrm{~m}$ to $+42 \mathrm{~m}$, the agreement of total modelled volume $\left(9.9 \mathrm{~km}^{3}\right)$ and interpolated volume from measurements $\left(10.0 \mathrm{~km}^{3}\right)$ was good. It should be emphasized that the model was calibrated to fit the mean thickness for all 79 glaciers, and was not optimized on these two glacier complexes. Hellstugubreen/Vestre Memurubreen consists of two valley glaciers joined by an ice divide, whereas Hardangerjøkulen exhibits a stronger maritime influence and is representative for a typical Norwegian ice 

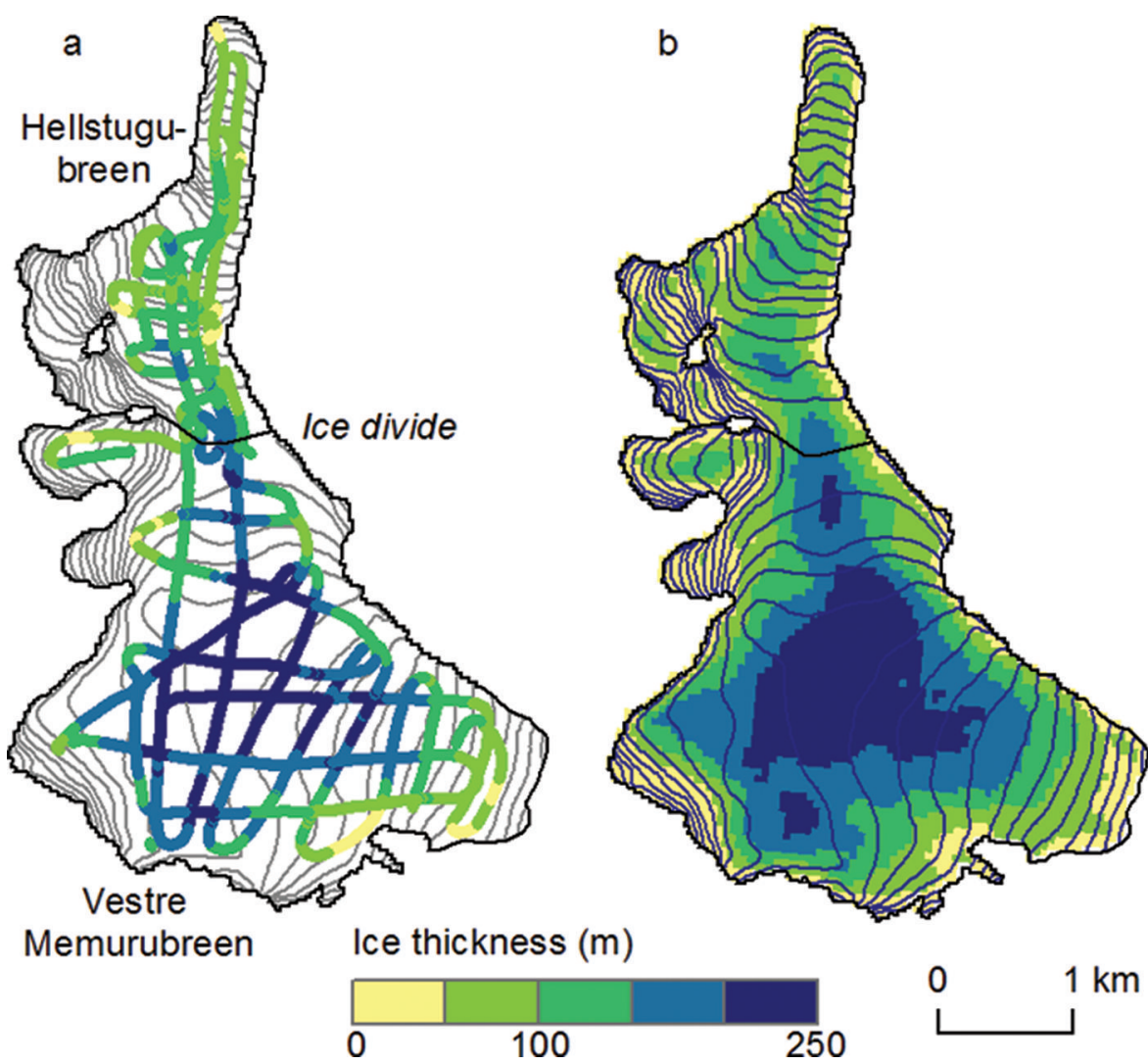

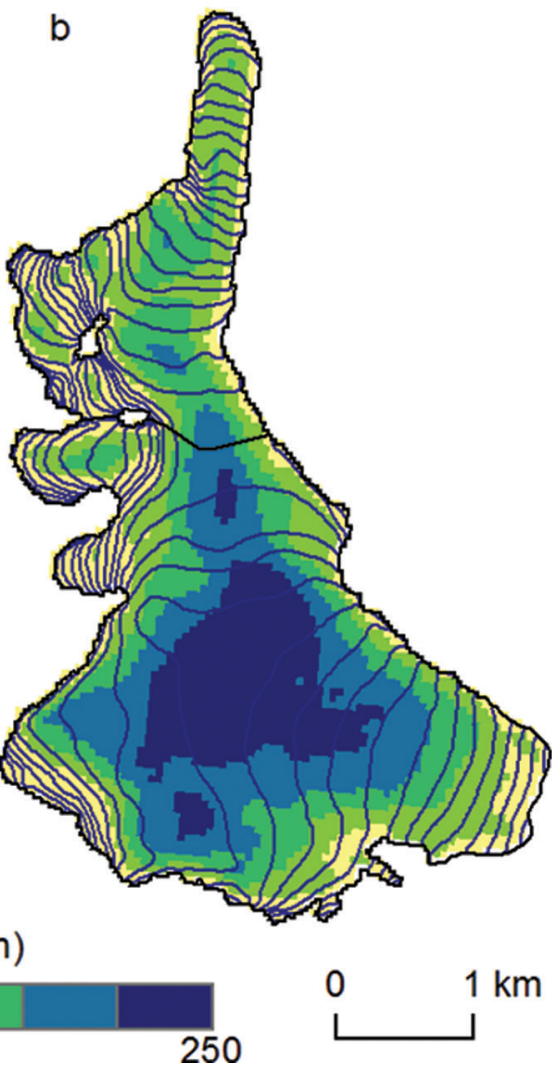

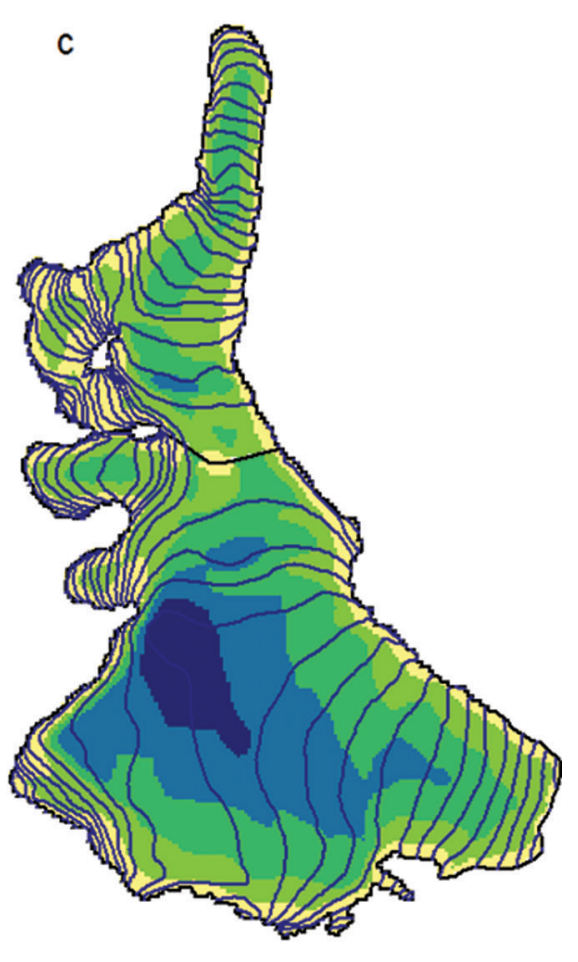

Fig. 4. Ice thickness of Hellstugubreen/Vestre Memurubreen with $50 \mathrm{~m}$ surface contours (glacier complex HMB; see Fig. 1 for location and Fig. 3 for reference). (a) Observed thickness points along profiles; (b) interpolated map from the measurements; and (c) ice thickness map computed from the distributed model.

cap. Thus, the results for these two quite densely measured complexes show that the model is capable of estimating ice volume in agreement with interpolated observations and that it performs reasonably well for different glacier types and climate conditions. Considering that only glacier outlines and a DTM are needed as model input and that the model, although based on physical assumptions, uses a simplified approach, the overall agreement is satisfying. Nevertheless, the mismatch can be significant for some sites, and results must be interpreted with care for individual glaciers.

Uncertainties in the model results stem from parameterizations in the model, as well as from uncertainties in the input data, namely the glacier area outlines and the DTM. Uncertainties in the glacier area are expected to be $\pm 3 \%$ (Andreassen and others, 2012b). If the glacier boundary is shifted relative to the underlying DTM, this can cause errors evaluated in glacier hypsometry and thus calculated ice thickness. However, all outlines were checked against the DTM20 during inventory generation, and shifts were found to be minor.

Following Huss and Farinotti (2012), we calculate the overall uncertainty in calculated ice volume, $\sigma_{\mathrm{v}}$, as

$$
\sigma_{\mathrm{v}}=\sqrt{\sigma_{M}^{2}+\sigma_{\text {DTM }}^{2}+\sigma_{\text {Area }}^{2}}
$$

where $\sigma_{M}, \sigma_{\text {Area }}$ and $\sigma_{\text {DTM }}$ are the uncertainties inherent to the modelling approach, the glacier area (outlines) and the DTM, respectively. The three individual uncertainties are assumed to be mutually uncorrelated. Thus, assuming an uncertainty of $\sigma_{\mathrm{M}}, \sigma_{\text {Area }}$ and $\sigma_{\text {DTM }}$ of $11 \%$ (according to Huss and Farinotti, 2012), $3 \%$ and $3 \%$ respectively gives an uncertainty of the total ice volume of Norway of $12 \%$.

\subsection{Other ice thickness estimates}

\subsubsection{Simple size scaling}

In the first inventory of north Scandinavia, few thickness data were available to estimate the ice volume, and a simple size scaling was used to estimate volume (Østrem and others, 1973): glaciers $<1 \mathrm{~km}^{2}$ were assumed to have a mean thickness of $25 \mathrm{~m}$, glaciers $1-5 \mathrm{~km}^{2}$ a mean thickness of $50 \mathrm{~m}$, glaciers $5-20 \mathrm{~km}^{2}$ a mean thickness of $125 \mathrm{~m}$, and

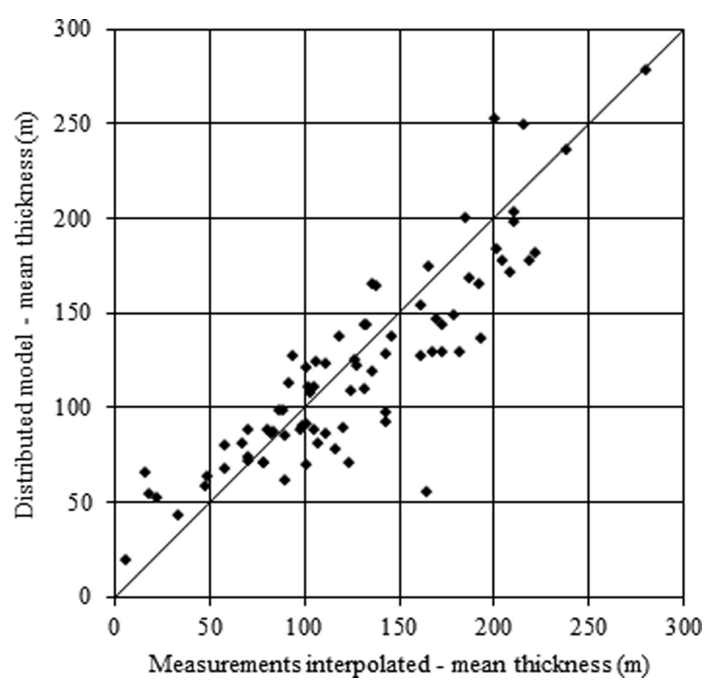

Fig. 5. Comparison of mean thickness calculated from the distributed model and interpolated from the measurements for 79 glaciers in Norway. 


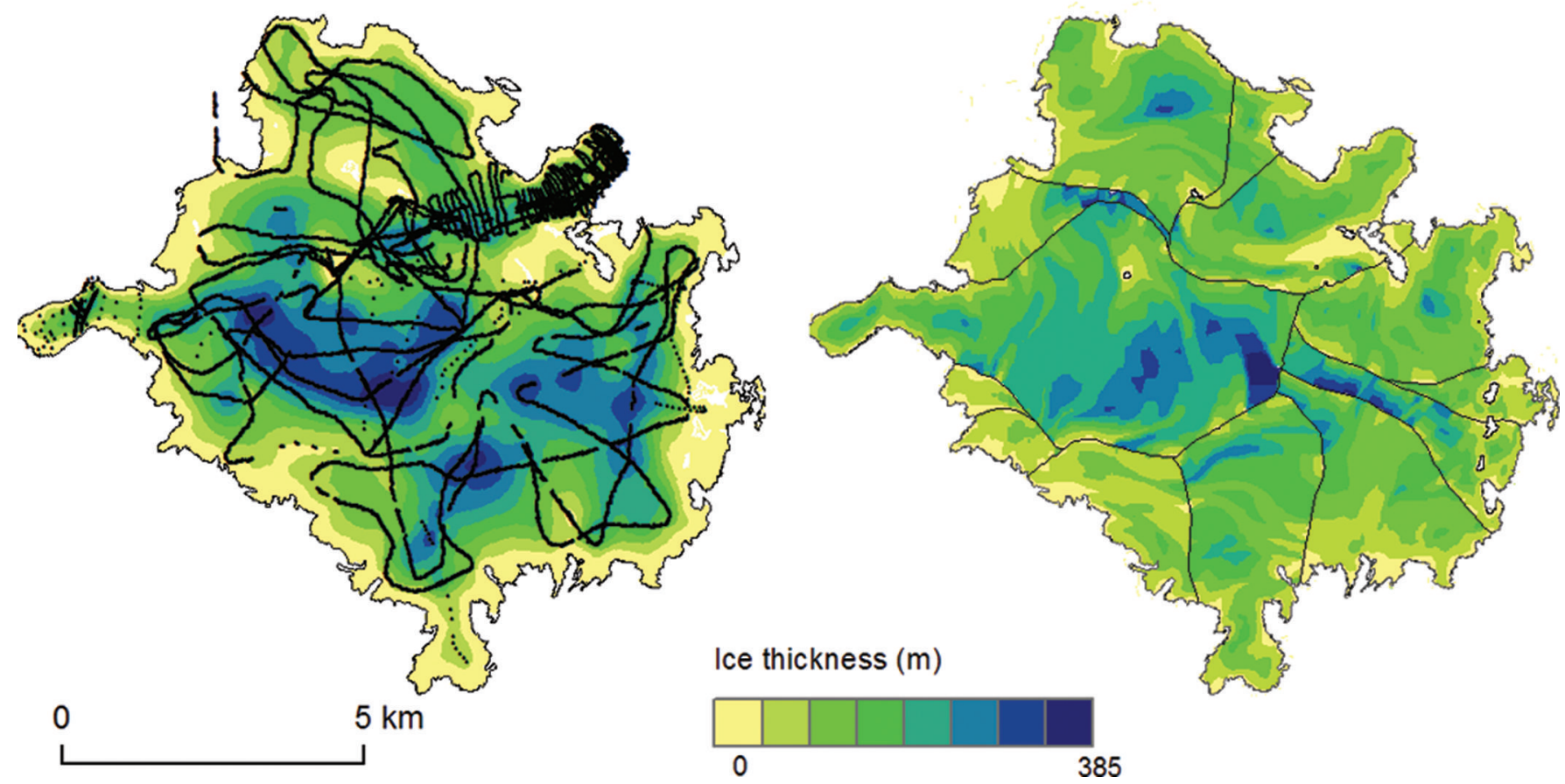

Fig. 6. Calculated ice thickness of Hardangerjøkulen (HAJ; see Fig. 1 for location). (a) Observed points along profiles and interpolated map from the measurements. (b) Ice thickness map computed from the distributed model for each flow unit.

glaciers $>20 \mathrm{~km}^{2}$ a mean thickness of $200 \mathrm{~m}$. We applied this simple size scaling to all 3143 glaciers in the 19992006 inventory.

\subsubsection{Volume-area scaling}

Glacier volume can be estimated from the surface area, $A$, using the scaling relationship

$$
V=C A^{\gamma}
$$

where $c$ and $\gamma$ are coefficients, usually derived from data, but values of $\gamma=1.375$ for glaciers and $\gamma=1.25$ for ice caps have also been inferred from theoretical considerations (Bahr, 1997). To estimate ice volume for Norwegian glaciers we obtained specific parameters directly from our ice thickness dataset (Fig. 7), and compared these to previously published scaling coefficients (Table 2). We also derived scaling parameters for the ice volume calculated from the distributed model for all 3143 glaciers in Norway.

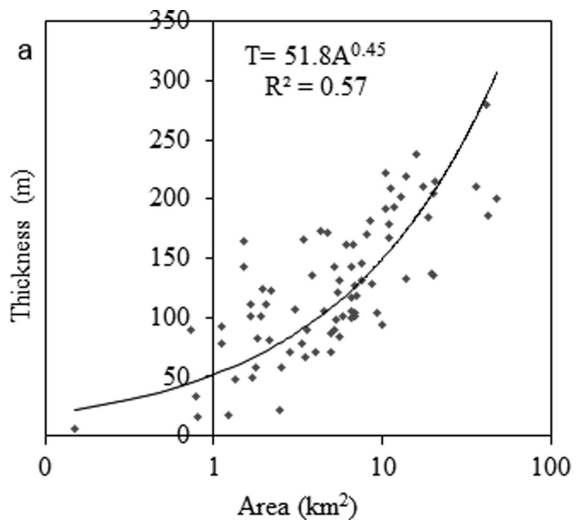

From the literature we selected laws that are used globally (Radić and Hock, 2010; Bahr, 2012; Grinsted, 2013) or for the European Alps (Chen and Ohmura, 1990). We used the scaling laws for glaciers and applied them to all glaciers. In addition, where separate scaling laws for glaciers and ice caps were given, we also applied the laws for ice caps for the 169 glacier complexes and the laws for glaciers for the 2366 single glaciers and calculated the volume as the sum of these. We do not calculate scaling coefficients for ice caps from our own dataset due to the small number (9) and their limited area range.

\section{RESULTS}

\subsection{Ice thickness observations}

Glaciers with available data are shown in Table 1. Measured maximum thicknesses range from $636 \mathrm{~m}$ at SvartisenVestisen (SVV) and $571 \mathrm{~m}$ at Jostedalsbreen to $16 \mathrm{~m}$ at the

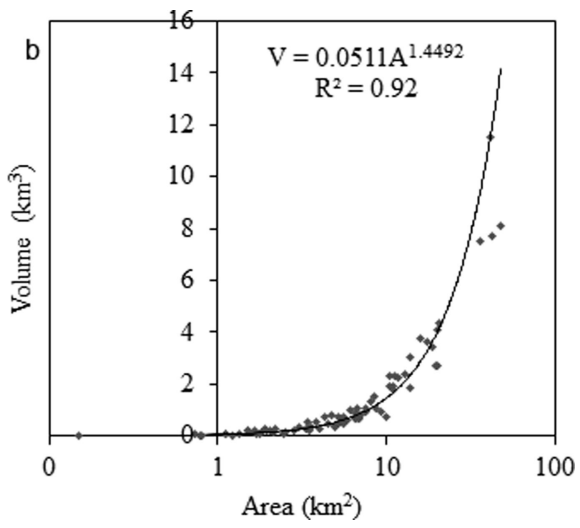

Fig. 7. Thickness-area (a) and $V-A$ scaling (b) relationship fitted to interpolated volume derived from ice thickness data for 79 glaciers. 
Table 2. Results of different volume-area scaling relationships applied to all Norwegian glaciers. Volume $V$ is estimated with Eqn (5). $V_{\mathrm{c}+\mathrm{s}}$ is the calculated total volume for glacier complexes + single glaciers, and $V_{\text {units }}$ for all glaciers

\begin{tabular}{|c|c|c|c|c|c|}
\hline Region & Glaciers & Ice caps & $V_{\mathrm{c}+\mathrm{s}}$ & $V_{\text {units }}$ & Source \\
\hline Alps & $V=0.0285 A^{1.357}$ & - & - & 137 & Chen and Ohmura (1990) \\
\hline Global & $V=0.033 A^{1.36}$ & - & - & 160 & Bahr (2012) \\
\hline Global & $V=0.0365 A^{1.375}$ & $V=0.0538 A^{1.250}$ & 359 & 183 & Radić and Hock (2010) \\
\hline Global & $V=0.0433 A^{1.29}$ & $V=0.0432 A^{1.23}$ & 188 & 184 & Grinsted (2013) \\
\hline Norway & $V=0.0511 A^{1.4492}$ & - & - & 300 & This study, 79 glaciers \\
\hline Norway & $V=0.0484 A^{1.4033}$ & - & - & 257 & This study, distr. model \\
\hline
\end{tabular}

ice patch Juvfonne. Except for this small ice patch, all glaciers have measured maximum ice thicknesses $>100 \mathrm{~m}$. Even for the small Storbreen $\left(5 \mathrm{~km}^{2}\right)$, maximum ice thickness was found to exceed $230 \mathrm{~m}$. Measurements on the six largest ice caps (Nos. 1-6 in Table 1) reveal ice thicknesses $>380 \mathrm{~m}$. The mean thickness interpolated from the measurements of the glaciers ranges from $6 \mathrm{~m}$ for Juvfonne to $279 \mathrm{~m}$ for Storglombreen (SVV). The estimated mean thickness of the ice caps ranges from 100 to $180 \mathrm{~m}$; the six largest have mean thicknesses $>140 \mathrm{~m}$. As an ice cap will have outlet glaciers with different mean thicknesses, some outlets will be thicker than the mean thickness of the entire ice cap. For example, Austdalsbreen $\left(10 \mathrm{~km}^{2}\right)$, an outlet glacier from Jostedalsbreen, has a mean thickness of $189 \mathrm{~m}$, whereas the mean thickness of the ice cap is estimated at $158 \mathrm{~m}$. Engabreen $\left(35.9 \mathrm{~km}^{2}\right)$ and Storglombreen $\left(41.2 \mathrm{~km}^{2}\right)$, outlets from Svartisen-Vestisen, have mean thicknesses of 210 and $279 \mathrm{~m}$, respectively, compared to the mean ice-cap thickness of $183 \mathrm{~m}$.

Regarding the ice caps it should be emphasized that data coverage may vary, and only at Hardangerjøkulen and Hellstugubreen/Vestre Memurubreen was interpolation to all flow units possible. Nevertheless, the results indicate that mean ice thickness is similar for all larger ice caps and weakly correlates with their total area. For example, the data interpolated from Jostedalsbreen $\left(474 \mathrm{~km}^{2}\right)$, Hardangerjøkulen $\left(71 \mathrm{~km}^{2}\right)$ and Blåmannsisen $\left(87 \mathrm{~km}^{2}\right)$ all reveal mean ice thicknesses of $\sim 150 \mathrm{~m}$ (Table 1 ). The somewhat higher mean thickness of Svartisen-Vestisen $\left(219 \mathrm{~km}^{2}\right)$, $183 \mathrm{~m}$, might be explained by the exclusion of smaller sub-basins due to insufficient data coverage.

Altogether, the area with ice thickness data available from direct interpolation of measurements accounts for $870 \mathrm{~km}^{2}$. The total volume is $134 \pm 23 \mathrm{~km}^{3}$, and the mean thickness for these glaciers is $155 \mathrm{~m}$. Ice thickness of the remaining parts can be expected to be smaller since measurements are biased towards the larger glaciers, with greater ice thicknesses. Assuming a mean ice thickness of all non-covered parts of $70 \pm 35 \mathrm{~m}$ gives an additional volume of $128 \pm 64 \mathrm{~km}^{3}$ and total ice volume estimate of $262 \pm 68 \mathrm{~km}^{3}$. This crude approach likely overestimates the mean thickness of small glaciers and underestimates the larger ice caps and glaciers, but provides a first estimate of the total ice volume, without involving modelling.

\subsection{Ice volume from distributed model}

The total volume estimate based on the calibrated distributed model is $280 \pm 34 \mathrm{~km}^{3}$. The 510 glaciers with an area $>1 \mathrm{~km}^{2}$ contribute $93 \%$ to the total volume, and, averaged over their area, the mean thickness is $124 \mathrm{~m}$. The mean thickness of the total glacier area in Norway is $104 \mathrm{~m}$. The estimated volume for Norway when running the model using the original globally applied parameter values by Huss and Farinotti (2012) is $\sim 14 \%$ lower $\left(240 \mathrm{~km}^{3}\right)$. According to the model, the 15 largest glacier complexes with an area of $1451 \mathrm{~km}^{2}$ (54\% of the total area) store $\sim 212 \mathrm{~km}^{3}$, which accounts for $76 \%$ of the total modelled volume.

Glaciers in the area range $0.1-0.5 \mathrm{~km}^{2}$ are numerous (43\% of the total number) and, with an area of $306 \mathrm{~km}^{2}$, contribute significantly to regional glacier coverage. According to the model results, glaciers smaller than 0.5 $(0.1) \mathrm{km}^{2}$ have a volume of $10.2(1.0) \mathrm{km}^{3}$. About 400 polygons with a total area of $24 \mathrm{~km}^{2}$ classified as 'possible snowfield', and without assigned glacier ID, were excluded from the glacier inventory and thus not interpolated or modelled. Most of them are $<0.1 \mathrm{~km}^{2}$. If we assume a mean thickness of 5 (10) $\mathrm{m}$ for these ice patches, they contribute a volume of $0.12(0.24) \mathrm{km}^{3}$ to the regional estimate, which is much smaller than the uncertainties in the volume estimates for large glaciers.

The calculated volume for all glaciers not covered by the interpolated ice thickness maps amounts to $137 \pm 16 \mathrm{~km}^{3}$. Adding this volume to the measured and interpolated volume gives a total volume estimate for Norway of $271 \pm 28 \mathrm{~km}^{3}$, slightly less than the $280 \mathrm{~km}^{3}$ using the modelled values for all, but well within the uncertainties in both estimates.

\subsection{Volume-area scaling relationships}

From the dataset of 79 glaciers we obtained a scaling constant $c=0.0511$ and an exponent $\gamma=1.4492$ (Eqn (5); Table 2; Fig. 7b). Using these coefficients resulted in a total ice volume estimate of $300 \mathrm{~km}^{3}$. Note that the dataset reveals a high correlation coefficient (coefficient of determination) of 0.75 (0.57) between thickness and area of these glaciers (Fig. 7a). In comparison, if using a subsample of 32 of the 79 glaciers considered to have the densest ice thickness data, values of $c=0.0486$ and $\gamma=1.4862$ were found, resulting in a slightly larger volume of $309 \mathrm{~km}^{3}$. Fitting a $V$ - $A$ scaling relation to the distributed model for all 3143 glaciers yields $c=0.0484$ and $\gamma=1.4033$, and a total ice volume of $257 \mathrm{~km}^{3}$ (Table 2).

The scaling laws and related estimates will vary depending on what is included or excluded. They are particularly sensitive to the mean thickness interpolation of the largest glaciers, and to some extent to how glacier complexes were divided into units in the inventory. A potential error source in scaling estimates is that too large an exponent leads to a positive bias in the total volume if it is applied to glaciers that are much larger than those in the calibration dataset (Grinsted, 2013). Then the $V-A$ relationship will show a more rapid decrease at the largest glacier sizes than the power law suggests (Bahr and Meier, 2000). However, in 


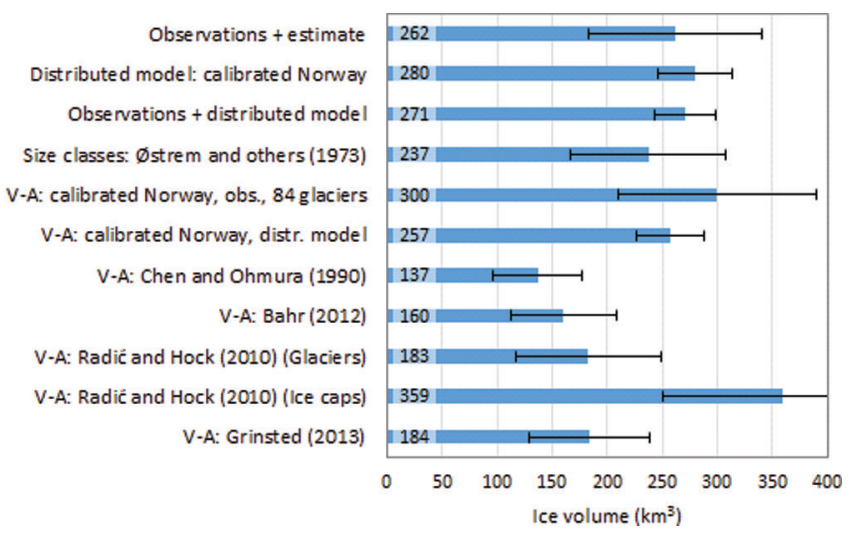

Fig. 8. Volume estimates of glaciers in Norway calculated by different methods. Simple size class scaling, interpolated from the thickness observations, results from distributed model, $V-A$ scaling relationships calibrated to the thickness observations and to the distributed model results and obtained from selected laws from the literature. See Table 2 for $V$ - $A$ scaling relationships. All calculations of $V$ shown here use the area of glaciers divided into units. Error bars are $12 \%$ for distributed model and $30 \%$ for $V$ - $A$ scaling.

our case, four of the five largest glaciers are included in the sample of 79 glaciers used for $V$-A calibration.

The total ice volume for Norway calculated from selected published scaling laws from the literature results in a wide range of values (Table 2; Fig. 8). When using these published scaling laws applied to glaciers divided into units, the volume estimates range from $137 \mathrm{~km}^{3}$ (Chen and Ohmura, 1990) to $184 \mathrm{~km}^{3}$ (Grinsted, 2013). On the other hand using separate laws for ice caps and glaciers (e.g. following Radić and Hock, 2010) gives a calculated ice volume of $359 \mathrm{~km}^{3}$ (336 and $23 \mathrm{~km}^{3}$, respectively, for ice caps and glaciers), which is nearly double that using their scaling law for glaciers applied to all 3143 individual glacier flow units $\left(183 \mathrm{~km}^{3}\right)$.

\section{DISCUSSION}

\subsection{Total volume}

The total ice volume calculated for glaciers in Norway substantially varies among the applied approaches (Fig. 8). The volume estimates calibrated with the ice thickness data (interpolated from measurements, distributed modelling and calibrated scaling) range from 257 to $300 \mathrm{~km}^{3}$ and are therefore within the uncertainty ranges of these individual approaches (Fig. 8). The size scaling estimate of Østrem and others (1973) is slightly smaller, $237 \mathrm{~km}^{3}$, whereas scaling laws from the literature give significantly smaller volumes when applying them for individual glaciers $\left(137-188 \mathrm{~km}^{3}\right)$. Just from the parts covered by measurements, an ice volume of $134 \pm 23 \mathrm{~km}^{3}$ was interpolated, and applying the simple extrapolation assuming a mean thickness of $70 \mathrm{~m}$ of all others gave a volume of $262 \pm 68 \mathrm{~km}^{3}$. This estimate is similar to the total estimate of $280 \pm 34 \mathrm{~km}^{3}$ from the distributed model. A 'best guess' of total volume might be obtained by combining the volume interpolated from the measurements and using the modelled volume for the remaining parts, which results in a total volume estimate for Norway of $271 \pm 28 \mathrm{~km}^{3}$.

Our scaling parameters derived for glaciers were higher than those of most other studies (Table 2; Grinsted, 2013).
Our glacier sample used for fitting scaling parameters was a combination of a few single glaciers and many outlet glaciers from ice caps. Although the glaciers that comprise ice caps are considered as individual flow units, they differ from classical valley glaciers by having greater thicknesses in the upper accumulation area, due to the high mass turnover of Norwegian ice caps. Results point to the need for local calibration of scaling laws to obtain better results in a given region. The mismatch between scaling laws from the literature and those obtained by calibration of local ice thickness measurements in our study may be similar for other maritime glacier regions (e.g. Patagonia and New Zealand).

In order to assess the effect of how the glaciers are divided into flow units or complexes on calculated total volume, we recalculated ice thickness with the distributed model. For this experiment the glacier complex outlines were used (no ice divides). The glacier complexes contribute $75 \%$ of the total area. The distributed model is expected to yield smaller accuracy for glacier complexes, as it is based on ice flow considerations. Total ice volume given by the model increased by $15 \%$ (from $280 \mathrm{~km}^{2}$ to $323 \mathrm{~km}^{2}$; the glacier complexes contribute $295 \mathrm{~km}^{2}$ and the single glaciers $28 \mathrm{~km}^{2}$ ). This indicates that the distributed model is sensitive to how the glaciers are divided and needs to be specifically calibrated to account for this. If total glacier volume is evaluated using the $V-A$ scaling relations for glacier complexes + single glaciers $\left(V_{\mathrm{c}+\mathrm{s}}\right)$ instead of glacier flow units $\left(V_{\text {units }}\right)$, results may differ substantially (Table 2). This indicates that the subdivision of glaciers into individual catchments is a major source of uncertainty in ice volume estimates, especially when they rely on scaling.

The distributed ice thickness model has a number of parameters that can be altered to achieve a better fit with observations. All parameters, however, refer to physical processes, are not freely variable and can be plausibilitychecked against independent field observations. For example, the calibrated optimal value of $d \widetilde{b} / d z_{0}$ is consistent with measured mass-balance gradients on Norwegian glaciers (Rasmussen and Andreassen, 2005), and good agreement was found. In order to analyse the sensitivity of the final volume result to the four most important model parameters, we performed a series of experiments and reran the model by individually varying these parameters within physically reasonable bounds (Table 3 ). The volume compared to the reference run was altered by up to $\pm 12 \mathrm{~km}^{3}$, or $\pm 4 \%$, for an individual parameter (Table 3). The results were almost insensitive to changing $f_{\text {cont }}$ and more sensitive to the assumed parameter values of $S_{\text {critt }}, d \widetilde{b} / d z_{0}$ and $A_{\mathrm{f}}$.

As the measured ice thickness data were obtained over several decades and the surface topography and the inventory data refer to different years, it is debatable whether our ice thickness and volume estimates are representative for today. Over the acquisition time interval of most ice thickness measurements (mid-1980s to 2013) Norwegian glaciers experienced transient mass surpluses, resulting in readvances of the glacier snouts for some glaciers but, at the same time, also mass deficit and frontal retreat (Andreassen and others, 2005). Since $\sim 2000$, most glaciers have been in a state of retreat. Over the past few decades, mass-balance observations show the largest thinning for Langfjordjøkelen (Andreassen and others, 2012a) and glaciers in Jotunheimen (Kjøllmoen and others, 2011). For these glaciers the thickness data were collected in recent years (2005-12). Most ice thickness data from 
Jostedalsbreen, Svartisen and Blåmannsisen were collected in the late 1980s. For these cases, however, ice thickness data are mainly based on bed topography maps, and the ice volume was evaluated from the most recent DTM, i.e. after 2000. Thus, although some data were acquired several decades ago, we estimate that our volume calculations refer to the mid-2000s, so they are assumed to be representative for current conditions.

Dense RES measurements with good spatial coverage are required to make accurate ice thickness maps of entire glaciers. However, ice thickness measurements are problematic in inaccessible areas such as crevassed icefalls, and interpretation of RES data can be difficult due to ambiguous reflections when approaching mountain walls (e.g. Fischer, 2009). While additional measurements on more glaciers are always desirable to cover all kinds of glacier types and area classes, the acquisition of RES data is time-consuming and expensive. The best recourse is to combine RES measurements with models.

Both the distributed model and $V-A$ scaling are sensitive to the chosen parameter values or the scaling coefficients. $V$-A scaling is straightforward to apply, easy to calibrate and quickly yields a regional volume estimate. While the distributed model has the advantage of providing ice thickness based on physical relations and gives a more detailed output, it also requires more input data and is fairly time-consuming to implement. However, the distributed model can also be calibrated with relatively few measurements, a benefit over the $V-A$ method given that RES coverage of entire glaciers is difficult to achieve and that volume calculated directly from sparse data has a larger uncertainty due to interpolation.

Applying different approaches, we derived a variety of estimates for total glacier volume in Norway (Fig. 8). Results vary over a wide range, from 137 to $359 \mathrm{~km}^{3}$, illustrating the considerable uncertainties in determination of regional ice volume. Although we do not know which of the inferred numbers is closest to reality, a clear pattern emerges from the methods used, giving at least some indication of the most plausible results. The four literature-based $V-A$ scaling relations do not contain any region-specific adjustment, and predict an average volume of only $166 \mathrm{~km}^{3}$. Volume estimates based on the direct observations of ice thickness, which cover only one-third of the Norwegian glacier area, are consistently higher and lie within a relatively narrow range (Fig. 8). The average overall volume from the extrapolated direct measurements, the calibrated ice thickness model and calibrated $V-A$ scaling relationships is $281 \mathrm{~km}^{3}, 69 \%$ higher than the uncalibrated scaling. Clearly, Norway is a region with a relatively large ice volume, given its glacier coverage; this might be attributed to its mostly maritime conditions, with high mass turnover and the gentle surface slopes in the accumulation area of ice caps.

\section{CONCLUSIONS}

We estimated the ice volume of glaciers in Norway by combining direct ice thickness observations with different modelling approaches and estimation methods. The extensive ice thickness measurements in Norway are geographically well distributed, covering about one-third of the entire glacier area, and include both small glaciers and the largest ice caps, making Norway one of the most densely surveyed regions worldwide. Except for some early investigations,
Table 3. Sensitivity of total ice volume to variations in selected model parameters used in the distributed model. The parameter value resulting in a higher volume is marked in bold

\begin{tabular}{lcccc}
\hline Parameter & Reference & Range & Unit & $\begin{array}{c}\Delta V \\
\mathrm{~km}^{3}\end{array}$ \\
\hline $\mathrm{d} b / \mathrm{d} z_{\mathrm{abl}, 0}$ & -0.007 & $0.0055 / \mathbf{0 . 0 0 8 5}$ & $\mathrm{m}$ w.e. $\mathrm{m}^{-1}$ & $-10.6 / 8.5$ \\
$S_{\text {crit }}$ & 10 & $\mathbf{6} / 20$ & $\mathrm{~km}^{2}$ & $6.7 /-12.2$ \\
$f_{\text {cont }}$ & 2400 & $1400 / 3400$ & $\mathrm{~m}$ & $-2.2 / 0.8$ \\
$A_{\mathrm{f}}(T=0)$ & 0.075 & $\mathbf{0 . 0 6} / 0.09$ & $\mathrm{bar}^{-3} \mathrm{a}^{-1}$ & $12.5 /-9.9$ \\
\hline
\end{tabular}

starting in the 1950s, most measurements were conducted from the 1980s onwards with RES. Measured and interpolated ice thickness values reveal relatively large and consistent ice thicknesses in the accumulation area of the largest ice caps; mean thickness varies insignificantly with their areas. The total volume of the area covered with RES data is $134 \pm 23 \mathrm{~km}^{3}$; simple extrapolation of the direct measurements gives a total volume of $262 \pm 68 \mathrm{~km}^{3}$. Applying a distributed ice thickness model, calibrated with the observations, yields a volume of $280 \pm 34 \mathrm{~km}^{3}$. The model results generally agreed with the measured values and interpolated ice volumes, but significant deviations in thickness were found for some outlet glaciers. The method has the advantage of providing grid-based ice thickness and bedrock topography maps, which are useful for other applications, such as the assessment of future glacier change or for hydrological studies. However, results must be interpreted with care for individual glaciers, since the precision is not considered high enough for detailed analyses (i.e. flow modelling).

Ice volumes obtained using volume-area scaling parameters from the literature have a higher range (137$359 \mathrm{~km}^{3}$ ), and are generally lower than those derived from region-specific scaling relationships calibrated using ice thickness measurements and distributed model results (257$309 \mathrm{~km}^{3}$ ). For glaciers in Norway, with their high mass turnover, previously published scaling relationships for glaciers underestimate ice volume; local calibration is needed to obtain reasonable results. We consider an estimate of $271 \pm 28 \mathrm{~km}^{3}$, derived from interpolated volume for the surveyed glaciers and the distributed model for the remaining glaciers, as the most reliable result for ice volume in Norway around the mid-2000s.

\section{ACKNOWLEDGEMENTS}

Jack Kohler and an anonymous reviewer provided constructive and helpful comments that improved the manuscript. We thank all those who contributed with ice thickness data. Galina Ragulina digitized bedrock maps of Jostedalsbreen and prepared the data for Trollbergdalsbreen. Ingvild Sørdal, Erlend Førre and Rune Ødegård provided data for Gråsubreen, Nordre Folgefonna and Juvfonne respectively. Trond Laumann digitized the bed map of Spørteggbreen. This is publication No. 69 of SVALI.

\section{REFERENCES}

Adhikari S and Marshall SJ (2012) Glacier volume-area relation for high-order mechanics and transient glacier states. Geophys. Res. Lett., 39(L16), L16505 (doi: 10.1029/2012GL052712) 
Andreassen LM, Elvehøy $\mathrm{H}$, Kjøllmoen B, Engeset RV and Haakensen N (2005) Glacier mass-balance and length variation in Norway. Ann. Glaciol., 42, 317-325

Andreassen LM, Kjøllmoen B, Rasmussen A, Melvold K and Nordli $\varnothing$ (2012a) Langfjordjøkelen, a rapidly shrinking glacier in northern Norway. J. Glaciol., 58(209), 581-593 (doi: 10.3189/ 2012JoG11J014)

Andreassen LM, Winsvold SH (eds), Paul F and Hausberg JE (2012b) Inventory of Norwegian glaciers. NVE Rep. 38-2012

Bahr DB (1997) Global distributions of glacier properties: a stochastic scaling paradigm. Water Resour. Res., 33, 1669-1679 (doi: 10.1029/97WR00824)

Bahr DB (2012) Estimation of glacier volume and volume change by scaling methods. In Encyclopedia of snow, ice and glaciers. Springer, Berlin, 278-280 (doi: 10.1007/SpringerReference_ 331076)

Bahr DB and Meier MF (2000) Snow patch and glacier size distributions. Water Resour. Res., 36, 495-501 (doi: 10.1029/ 1999WR900319)

Bahr DB, Meier MF and Peckham S (1997) The physical basis of glacier volume-area scaling. J. Geophys. Res., 102, 20355-20362

Bull C and Hardy JR (1957) The determination of the thickness of a glacier from measurements of the value of gravity. J. Glaciol., 2(20), 755-762

Chen J and Ohmura A (1990) Estimation of Alpine glacier water resources and their change since 1870s. IAHS Publ. 193 (Symposium at Lausanne - Hydrology in Mountainous Regions l), 127-135

Clarke GKC, Berthier E, Schoof CG and Jarosch AH (2009) Neural networks applied to estimating subglacial topography and glacier volume. J. Climate, 22, 2146-2160 (doi: 10.1175/ 2008JCLI2572.1)

Clarke GKC and 6 others (2013) Ice volume and subglacial topography for Western Canadian glaciers from mass balance fields, thinning rates, and a bed stress model. J. Climate, 26, 4282-4303 (doi: 10.1175/JCLI-D-12-00513.1)

Cogley JG (2012) The future of the world's glaciers. In HendersonSellers A and McGuffie K eds The future of the world's climate, 2nd edn. Elsevier, Amsterdam, 197-222

Elvehøy $\mathrm{H}$, Engeset R, Andreassen LM, Kohler J, Gjessing $\mathrm{Y}$ and Björnsson H (2002) Assessment of possible jökulhlaups from Lake Demmevatnet in Norway. IAHS Publ. 271 (Symposium at Reykjavik - Extremes at the Extremes), 31-36

Farinotti D and Huss M (2013) An upper-bound estimate for the accuracy of glacier volume-area scaling. Cryosphere, 7, 17071720 (doi: 10.5194/tc-7-1707-2013)

Farinotti D, Huss M, Bauder A, Funk M and Truffer M (2009) A method to estimate ice volume and ice-thickness distribution of alpine glaciers. J. Glaciol., 55(191), 422-430

Fischer A (2009) Calculation of glacier volume from sparse icethickness data, applied to Schaufelferner, Austria. J. Glaciol., 55(191), 453-460

Fischer A. and Kuhn M (2013) GPR measurements of 64 Austrian glaciers as a basis for a regional glacier volume inventory. Ann. Glaciol., 54(64), 179-188

Førre E (2012) Topografi og dreneringsretninger under Nordfonna, Folgefonna. Masteroppgave. (Master's thesis, Geophysical Institute, University of Bergen)

Glen JW (1955) The creep of polycrystalline ice. Proc. R. Soc. London, Ser. A, 228(1175), 519-538

Grinsted A (2013) An estimate of global glacier volume. Cryosphere, 7, 141-151

Gudmundsson GH (1999) A three-dimensional numerical model of the confluence area of Unteraargletscher, Bernese Alps, Switzerland. J. Glaciol., 45(150), 219-230

Haakensen N and Wold B (1986) Breheimen - Stryn. Undersøkelse av bunntopografi på Bødalsbreen. NVE Rapp. 17-1986

Haeberli W and Hoelzle M (1995) Application of inventory data for estimating characteristics of and regional climate-change effects on mountain glaciers: a pilot study with the European Alps. Ann. Glaciol., 21, 206-212

Hallaråker BEW and Lohne PF (2013) Application of ground penetrating radar to estimate the volume of Austerdalsbreen, West Norway. (Bachelor thesis, Sogn and Fjordane University College) Hock R, Rees G, Williams MW and Ramirez E (2006) Preface: Contribution from glaciers and snow cover to runoff from mountains in different climates. Hydrol. Process., 20(10), 2089-2090

Huss M and Farinotti D (2012) Distributed ice thickness and volume of all glaciers around the globe. J. Geophys. Res., 117(F4), F04010 (doi: 10.1029/2012JF002523)

Hutchinson MF (1989) A new procedure for gridding elevation and stream line data with automatic removal of spurious pits. J. Hydrol., 106(3-4), 211-232

Jones JAA (1999) Climate change and sustainable water resources: placing the threat of global warming in perspective. Hydrol. Sci. J., 44(4), 541-557 (doi: 10.1080/02626669909492251)

Kargel, JS, Leonard GJ, Bishop MP, Kääb A, and Raup BH (2014) Global Land Ice Measurements from Space. Springer-Praxis Books, Berlin and Heidelberg

Kennett M (1989a) Feltavgrensning på nordre Jostedalsbreen. NVE Rapp. 2-1989

Kennett M (1989b) Kartlegging av istykkelse og feltavgrensning på Spørteggbreen 1989. NVE Rapp. 15-1989

Kennett M (1990) Kartlegging av istykkelse og feltavgrensning på Blåmannsisen 1990. NVE Rapp. 8-1990

Kennett $M$ and Elvehøy, $H$ (1995) Bestemmelse av dreneringsgrenser for inntak til Svartisen Kraftverk. NVE Rapp. 22-1995

Kennett $M$ and Sætrang AC (1987) Istykkelsesmålinger på Folgefonna. NVE Oppdragsrapp. 18-1987

Kennett M, Laumann T and Lund C (1993) Helicopter-borne radioecho sounding of Svartisen, Norway. Ann. Glaciol., 17, 23-26

Kjøllmoen B (2006) Hydrologiske undersøkelser ved Maurangervassdraget. NVE Oppdragsrapp., ser. B, 2-2006

Kjøllmoen B and Engeset R (2003) Glasiologiske undersøkelser på Harbardsbreen 1966-2001. Sluttrapport. NVE Oppdragsrapp. 12003

Kjøllmoen B and Kennett M (1995) Breundersøkelser på Svartisheibreen 1988-94. NVE Rapp. 17-1995

Kjøllmoen B (ed.), Andreassen LM, Elvehøy H, Jackson M and Giesen RH (2011) Glaciological investigations in Norway in 2010. NVE Rep. 3-2011

Linsbauer A, Paul F and Haeberli W (2012) Modeling glacier thickness distribution and bed topography over entire mountain ranges with GlabTop: application of a fast and robust approach. J. Geophys. Res., 117(F3), F03007 (doi: 10.1029/2011JF002313)

Meier MF and 7 others (2007) Glaciers dominate eustatic sea-level rise in the 21 st century. Science, 317(5841), 1064-1067

Melvold K, Laumann T and Nesje A (2011) Kupert landskap under Hardangerjøkulen. Geo, 36-37

Moran ML, Greenfield RJ, Arcone SA and Delaney AJ (2000) Delineation of a complexly dipping temperate glacier bed using short-pulse radar arrays. J. Glaciol., 46(153), 274-286

Navarro F and Eisen O (2010) Ground-penetrating radar in glaciological applications. In Pellikka P and Reese WG eds Remote sensing of glaciers: techniques for topographic, spatial and thematic mapping of glaciers. Taylor \& Francis, London, 195-229

NGU (Norges geologiske undersøkelse) (1964) Seismiske undersøkelser på Folgefonni, 27. april - 3. juni. (Rapport 545)

Nye JF (1965) The flow of a glacier in a channel of rectangular, elliptic or parabolic cross-section. J. Glaciol., 5(41), 661-690

Ødegård RS, Nesje A, Isaksen K and Eiken T (2011) Perennial ice patch studies - preliminary results from a case study in Jotunheimen, southern Norway. Geophys. Res. Abstr., 13, EGU2011-12027

Østrem G, Haakensen N and Melander O (1973) Atlas over breer i Nord-Skandinavia (Glacier atlas of Northern Scandinavia). NVE Nor. Vassdrags- og Energiv. Medd. 22 
Østrem G, Liestøl O and Wold B (1976) Glaciological investigations at Nigardsbreen, Norway. Nor. Geogr. Tidsskr. 30, 187209

Østrem G, Dale Selvig K and Tandberg K (1988) Atlas over breer i Sør-Norge (Atlas of glaciers in South Norway). NVE Nor. Vassdrags- og Energiv. Medd. 61

Paul F and Linsbauer A (2012) Modeling of glacier bed topography from glacier outlines, central branch lines, and a DEM. Int. J. Geogr. Inf. Sci., 26, 1173-1190 (doi: 10.1080/13658816. 2011.627859)

Paul F and 9 others (2009) Recommendations for the compilation of glacier inventory data from digital sources. Ann. Glaciol., 50, 119-126 (doi: 10.3189/172756410790595778)

Pettersson R, Christoffersen P, Dowdeswell J, Pohjola V and Hubbard A (2011) Ice thickness and basal conditions of Vestfonna ice cap, eastern Svalbard. Geogr. Ann. A, 93, 311-322

Pfeffer WT and 75 others (2014). The Randolph Glacier Inventory: a globally complete inventory of glaciers. J. Glaciol., 60(221), 537-552 (doi: 10.3189/2014JoG13J176)

Racoviteanu AE, Paul F, Raup B, Khalsa SJS and Armstrong R (2009) Challenges and recommendations in mapping of glacier parameters from space: results of the 2008 Global Land Ice Measurements from Space (GLIMS) workshop. Boulder, Colorado, USA. Ann. Glaciol., 50(53), 53-69

Radić V and Hock R (2010) Regional and global volumes of glaciers derived from statistical upscaling of glacier inventory data. J. Geophys. Res., 115(F1), F01010 (doi: 10.1029/ 2009JF001373)

Rasmussen LA and Andreassen LM (2005) Seasonal mass-balance gradients in Norway. J. Glaciol., 51(175), 601-606
Roland E (1986) Antatte endringer på Austdalsbreen og Sygneskardbreen etter regulering på Austdalsvatn og Kupvatn. NVE Rapp. 13-1986

Sætrang AC (1988) Kartlegging av istykkelse på Vestre Svartisen 1986. NVE Oppdragsrapp. 3-1988

Sætrang AC and Holmqvist E (1987) Kartlegging av istykkelse på nordre Jostedalsbreen. NVE Rapp. 8-1987

Sætrang AC and Wold B (1986) Results from the radio echosounding on parts of the Jostedalsbreen ice cap, Norway. Ann. Glaciol., 8, 156-158

Sellevold MA and Kloster K (1964) Seismic measurements on the glacier Hardangerjøkulen, Western Norway. Nor. Polarinst. Årb., 1964, 87-91

Sørdal I (2013) Kartlegging av temperaturtilhøva i Gråsubreen og Juvfonne. Masteroppgåve. (Master's thesis, University of Oslo)

Sverrisson M, Johannesson $Æ$ and Bjørnsson H (1980) Instruments and methods. Radio-echo equipment for depth sounding of temperate glaciers. J. Glaciol., 25(91), 477-486

Van de Wal RSW and M Wild (2001) Modelling the response of glaciers to climate change, applying volume-area scaling in combination with a high resolution GCM. Climate Dyn., 18, 359-366

Vaughan DG and 13 others (2013) Observations: cryosphere. In Stocker TF and 9 others eds Climate change 2013: the physical science basis. Contribution of Working Group I to the Fifth Assessment Report of the Intergovernmental Panel on Climate Change. Cambridge University Press, Cambridge and New York Ward WH (1961) Experiences with electro-thermal ice drills on Austerdalsbre, 1956-59. IAHS Publ. 54 (General Assembly of Helsinki 1960 - Snow and Ice), 532-542

MS received 29 August 2014 and accepted in revised form 19 May 2015 